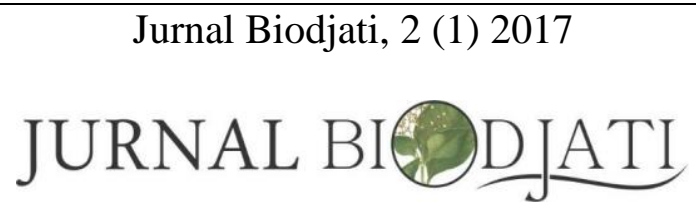

http://journal.uinsgd.ac.id/index.php/biodjati

\title{
STUDI AWAL KULTUR BIJI SOWANG (Xanthostemon novaguineense Valet.) SECARA IN-VITRO
}

\author{
Sri Wilujeng', Verena Agustini \\ ${ }^{1}$ Program Studi Kehutanan, Fakultas Kehutanan, Universitas Winaya Mukti \\ ${ }^{2}$ Jurusan Biologi, FMIPA, Universitas Cenderawasih
}

\begin{tabular}{l}
\hline Diterima 21 April 2017 \\
Disetujui 28 Mei 2017 \\
Publish 31 Mei 2017 \\
\hline
\end{tabular}

Korespondensi :

e-mail :

${ }^{1}$ sriwilujeng@yahoo.co.id

²verena.agustini@gmail.com

e-ISSN : 2541-4208

p-ISSN : 2548-1606

Abstrak. Sowang (Xanthostemon novoguineense Valet.) diidentifikasi sebagai spesies endemik Papua. X. novaguineense merupakan jenis tumbuhan New Guinea bagian barat dengan data ilmiah yang sangat terbatas. Di alam, jumlah tegakan dan habitat sowang saat ini telah menyusut karena eksploitasi hasil hutan dan konversi lahan. Sementara eksploitasi kayu sowang dan konversi habitat sowang tetap berlangsung, usaha meregenerasi belum tampak di masyarakat, kemampuan regenerasi sowang secara alamijuga sangat rendah. Hal ini merupakan ancaman kepunahan bagi populasi sowang.Penelitian ini dilakukan untuk mengidentifikasi media in-vitro yang sesuai bagi perkecambahan biji dan pertumbuhan tunas sowang. Percobaan dirancang dengan memperlakukan dua jenis media perkecambahan yakni VW yang dimodifikasi dan MS dengan zpt, 20 ulangan, setiap satu unit percobaan berisi 30 benih sowang yang ditanam di media, dilakukan di laboratorium kultur jaringan FMIPA Universitas Cenderawasih Jayapura. Variabel penelitian adalah hari muncul tunas, persen perkecambahan, penampilan tunas dan tinggi tunas pada usia tunas 60 hari. Data dianalisis dengan independent sample t test. Hasil penelitian menunjukkan tidak terdapat signifikansi pada variabel-variabel hari muncul tunas, persen perkecambahan, penampilan tunas dan tinggi tunas antara perlakuan media VW yang dimodifikasi danMS dengan zpt. Rata-rata hari muncul tunas adalah 5.50 hari dan 5.55hari, rata-rata persen perkecambahan adalah $63.55 \%$ dan $61.40 \%$, rata-rata skor penampilan tunas adalah 2.85 dan 2.75 serta rata-rata panjang tunas adalah2.84 cm dan $2.67 \mathrm{~cm}$.

Kata kunci : sowang, endemik, regenerasi, in-vitro.

\begin{abstract}
Sowang (Xanthostemon novoguineense Valet.) is identified as an endemic species of Papua. X. Novaguineense,originated from west New Guinea, is a species with limited scientific information. Nowadays, in its own habitat, sowang's quantity of sapling and area population has been decreasing for exploitations and land conversions. As those exploitations and land conversions occur, and with sowang low natural regeneration ability, there still no community effort for sowang regeneration. It is endangering sowang population to extinction.The study was conducted to identify in-vitro media suitable for seed germination and seedling growth of sowang. The experimental units were set up using two germination media, modified $V W$ and $M S$ with zpt, in tissue culture laboratory of FMIPA Cenderawasih University. Each experiment was carried out to
\end{abstract}




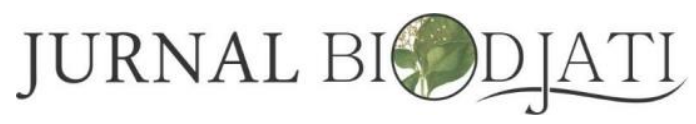

http://journal.uinsgd.ac.id/index.php/biodjati

include 30 seeds, and then replicated 20 times. Observed variable were days count of germination, seedling percentage, seedling appearance and height on age 60 days. The data were analyzed using independent sample $t$ test. The result showed no significant effect on observed variables between modified VW media and MS with zpt media treatment.The average days of seedling to appear are 5.50 days and 5.55 days, the average seedling percentage are $63.55 \%$ and $61.40 \%$, the average or appearance score on age 60 days are 2.85 and 2.75 while the average of seedling height are $2.84 \mathrm{~cm}$ and $2.67 \mathrm{~cm}$ respectively.

Key words: sowang, endemic, regeneration, in-vitro

\section{Cara Sitasi}

Wilujeng, S., \& Agustini, V. (2017). Studi Awal Kultur Biji Sowang (Xanthostemon novaguineense Valet.) Secara In-Vitro. Jurnal Biodjati, 2 (1), 64-71.

\section{PENDAHULUAN}

Sowang (Xanthostemon novoguineense Valet.) diidentifikasi oleh Whitmore et al. (1997) merupakan spesies endemik Papua. Wilson \& Pitisopa (2007) mengemukakan bahwa $X$. Novaguineense merupakan jenis tumbuhan New Guinea bagian barat dengan data ilmiah yang sangat terbatas. Pernyataan ini sesuai dengan kondisi sekarang bahwa belum ada laporan ilmiah yang komprehensif mengenai $X$. novaguineense. Beberapa studi tentang sowang belum memiliki validitas yang dapat diverifikasi secara ilmiah sehingga informasi yang ada tidak dapat digunakan sebagai acuan.

Daerah habitat tumbuhan sowang di Jayapura adalah pegunungan Cycloop. Pegunungan Cycloop terletak membujur di sebelah utara kota dan kabupaten Jayapura. Sowang tumbuh tidak merata di Pegunungan Cycloop. Sowang hanya tumbuh di sisi barat, selatan sampai timur Pegunungan Cycloop. Sowang memiliki ketahanan terhadap api atau kebakaran tetapi memiliki daya regenerasi yang sangat rendah. Di alam, jumlah tegakan dan habitat sowang saat ini telah menyusut karena eksploitasi hasil hutan dan konversi lahan. Eksploitasi kayu sowang dilakukan oleh masyarakat tradisional secara besar-besaran. $\begin{array}{ccc}\text { Kekuatan kayu sowang merupakan } & \text { melakukan }\end{array}$ eksploitasi kayu ini. Konversi lahan terjadi karena perluasan pemukimam dan pembangunan di kota dan kabupaten Jayapura. Sementara eksploitasi kayu sowang dan konversi habitat sowang tetap berlangsung, usaha meregenerasi belum tampak di masyarakat, regenerasi sowang berlangsung secara alami. Hal ini merupakan ancaman kepunahan bagi populasi sowang (Wilujeng, 2010).

Biji sowang berbentuk bulat pipih dengan diameter 1,5-2 $\mathrm{mm}$, ringan, tidak berbulu dan tidak bersayap (Wilujeng \& Simbiak, 2014). Ukuran biji sowang termasuk dalam kategori biji yang sangat kecil. Tidak semua proses perkecambahan biji berukuran kecil memiliki kemampuan menumbuhkan dan membuatakar berfungsi tepat pada saat dibutuhkan. Hal ini diduga terjadi pada biji sowang. Hasil penelitian Wilujeng \& Agustini (2017) menunjukkan bahwa daya kecambah sowang yang disemai di media tanah tempat tumbuhnya, sangat rendah (tertinggi $18 \%$ ). Benih sowang mulai berkecambah pada 10 hari setelah tanam (hst) hingga mencapai puncak pada 17 hst, kemudian anakan sowang berangsur-angsur mati sejak 21 hst hingga mati secara keseluruhan pada 38 hst. 


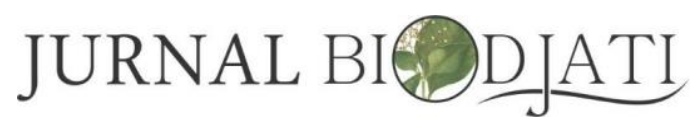

http://journal.uinsgd.ac.id/index.php/biodjati

Anggrek (Orchidaceae) memiliki biji yang sangat kecil dan ringan, bahkan diketahui tidak memiliki endosperm, untuk dapat berkecambah dengan keberhasilan tinggi, biji anggrek umumnya memerlukan kondisi aseptik in-vitro dengan suplai energi dan hara mineral yang lengkap pada media kulturnya. Formulasi media yang dapat digunakan untuk mengecambahkan biji anggrek diantaranya adalah Knudson C, Vacin dan Went (VW) atau Murashige dan Skoog (MS) yang mengandung garam mineral esensial bagi pertumbuhan anakan dari biji anggrek. Penelitian dengan menggunakan media dasar MS menunjukkan bahwa media MS dapat dijadikan media perkecambahan dan pertumbuhan Phalaenopsis hibrida. Pada tingkat perkecambahan media MS menghasilkan jumlah kecambah lebih rendah dibandingkan dengan media growmore (Yusnita \& Handayani, 2011).

Untuk memperoleh anakan sowang yang memiliki kemampuan bertahan hidup di habitat aslinya, diperlukan perlakuan khusus pada saat biji berkecambah hingga menjadi anakan. Perlakuan khusus dimaksud adalah persemaian biji dengan kultur in-vitro. Penggunaan kultur in-vitro bertujuan untuk mengantisipasi anakan kehilangan sumber nutrisi karena endosperm yang kecil sementara akar belum berfungsi optimal.

\section{BAHAN DAN METODE}

\section{Waktu dan Lokasi Penelitian}

Penelitian dilakukan di Doyo Baru Kabupaten Jayapura untuk pengambilan biji sowang. Pelaksanaan kultur in-vitro dilakukan di laboratorium kultur jaringan FMIPA Universitas Cenderawasih.

\section{Pelaksanaan Penelitian}

Penelitian ini dirancang menggunakan dua perlakuan yakni penggunaan media tanam in-vitro. Perlakuan pertama adalah penggunaan media tanam VW yang dimodifikasi dengan penambahan air kelapa dan sari tomat. Perlakuan kedua adalah media MS dengan zat pengatur tumbuh (zpt). Percobaan diulang 20 kali sehingga diperoleh 40 satuan percobaan.

\section{Pelaksanaan Percobaan \\ Sterilisasi Alat}

Sterilisasi dilakukan terhadap botol kultur, scalpel, pinset dan petridish. Peralatan dicuci dengan menggunakan detergen, dibilas, kemudian dikeringkan. Alat-alat yang sudah kering dibungkus dengan kertas (kecuali botol kultur). Semua alat tersebut disterilisasi dengan autoclave selama 45 menit.

\section{Pembuatan Media Tanam}

Penimbangan dilakukan terhadap masing-masing bahan hara makro dan hara mikro sesuai komposisi media dasar VW dan MS dengan penambahan $20 \mathrm{~g}$ sukrosa dan $12 \mathrm{~g}$ agar. Untuk media VW ditambahkan $150 \mathrm{ml}$ air kelapa dan $50 \mathrm{ml}$ sari tomat, sementara untuk media MS ditambahkan $2 \mathrm{mg}$ Benzyl Adenine (BA) dan 6 mgNapthalene Acetic Acid (NAA). Aquades ditambahkan hingga volume larutan mencapai $1000 \mathrm{~mL}$. Larutan diaduk dan dididihkan.Larutan dikondisikan pada kisaran $\mathrm{pH} 5-6$ dengan menggunakan $\mathrm{NaOH}$ dan $\mathrm{HCl}$. Kemudian larutan dituangkan ke dalam botol kultur, sebanyak $25 \mathrm{~mL}$ setiap botol. Botol ditutup dengan aluminium foil, sterilisasi dengan autoclave selama 45 menit. Setelah itu, botol-botol ditempatkan pada rakrak kultur.

\section{Sterilisasi Biji dan Penanaman}

Biji dipindahkan ke kertas saring, dilipat kemudian dilakukan sterilisasi dengan merendam biji dalam larutan chlorox $20 \%$. Perendaman dilakukan selama 30 menit lalu dipindahkan ke aquadest selama 5 menit, 


\section{JURNAL BIDDJATI}

http://journal.uinsgd.ac.id/index.php/biodjati

diulangi 3 kali. Pada saat biji dipindah dalam aquadest, pemindahan dilakukan dalam keadaan steril di dalam Laminar Air Flow (LAF). Biji dalam kertas saring yang telah disterilisasi kemudian diletakkan pada petridish, biji diambil dengan menggunakan jarum ose dan diinokulasikan pada media dalam botol sesuai dengan perlakuan. Setiap botol merupakan satu unit percobaan, ditanam 30 biji sowang. Botol ditutup dengan aluminium foil, dilapisi dengan plastik prophopilen. Semua proses penanaman ini dilakukan di dalam LAF.

\section{Pemeliharaan}

Pemeliharaan botol-botol kultur berisi biji dilakukan dengan cara meletakkan pada rak-rak kultur. Untuk mencegah kontaminasi, botol-botol tersebut disemprot dengan alkohol $70 \%$ setiap dua hari sekali.

\section{Pengamatan dan Pengumpulan Data}

Pengamatan dilakukan terhadap pertumbuhan tunas. Parameter pengukuran adalah :

a. Hari muncul tunas (hari)

Pengamatan dilakukan setiap hari dengan menghitung hari saat muncul tunas pertama kali yang dinyatakan dalam hst (hari setelah tanam). Angka hst ditandai dengan adanya pembengkakan atau munculnya jaringan kehijauan pada permukaan biji. Angka hari muncul tunas merupakan hari pertama salah satu atau lebih biji berkecambah dalam satu unit percobaan.

b. Persen perkecambahan (\%)

Pengamatan dilakukan dengan menghitung biji yang berkecambah pada hari terakhir percobaan. Angka persen perkecambahan merupakan persentase dari biji yang berkecambah dari semua biji yang diinokulasi dalam satu unit percobaan. c. Penampilan tunas (skor)

Pengamatan tunas dilakukan pada akhir percobaan secara visual. Pengamatan dilakukan dengan cara pemberian nilai dimana penampakan tunas yang terbentuk dibagi ke dalam 4 skor (Gultom et al., 2012) yakni :

$0=$ Biji tidak berkecambah

1 = Biji berkecambah, tunas tidak sempurna

2 = biji berkecambah, tunas kurang sempurna

3 = biji berkecambah, tunas sempurna

Angka penampilan tunas merupakan rata-rata skor penampilan tunas pada umur 60 hari setelah biji pertama berkecambah, dalam satu unit percobaan.

4 = Panjang tunas $(\mathrm{cm})$

Panjang tunas diukur pada akhir percobaan mulai dari tempat munculnya tunas (pangkal) sampai ujung tunas terpanjang. Angka panjang tunas merupakan hasil rata-rata panjang tunas pada umur 60 hari setelah biji pertama berkecambah, dalam satu unit percobaan.

\section{Analisis Data}

Data hasil penelitian dianalisis dengan independent sample $t$ test menggunakan SPSS versi 20.

\section{HASIL}

Pada percobaan ini biji sowang diinokulasi pada media in-vitro yang berbeda yakni VW yang dimodifikasi dan MS dengan zpt. Parameter yang diamati adalah hari muncul tunas (hst), persen perkecambahan (\%), rata-rata skor penampilan tunas (skor) dan rata-rata panjang tunas $(\mathrm{cm})$. 


\section{Jurnal Biodjati, 2 (1) 2017

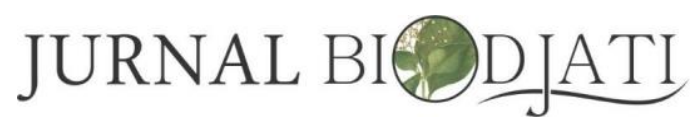

http://journal.uinsgd.ac.id/index.php/biodjati
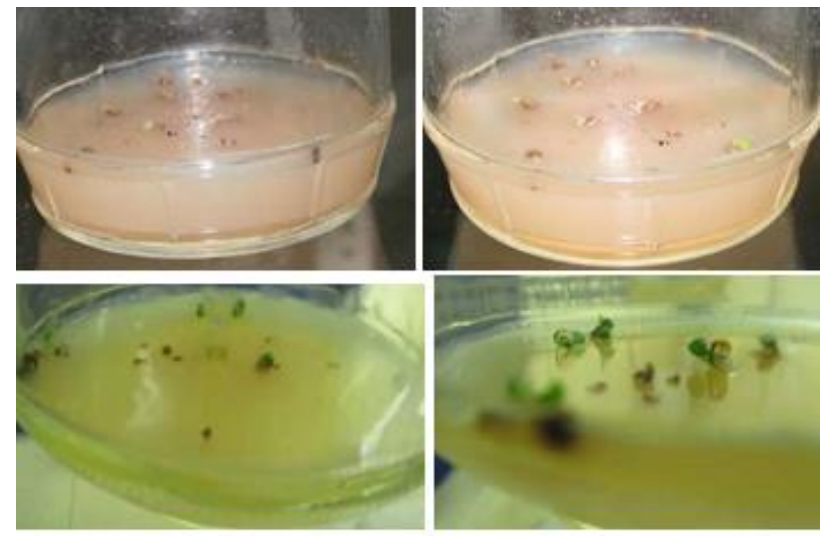

Gambar 1. Biji sowang yang diinokulasi pada media VW yang dimodifikasi (atas) dan media MS dengan zpt (bawah).

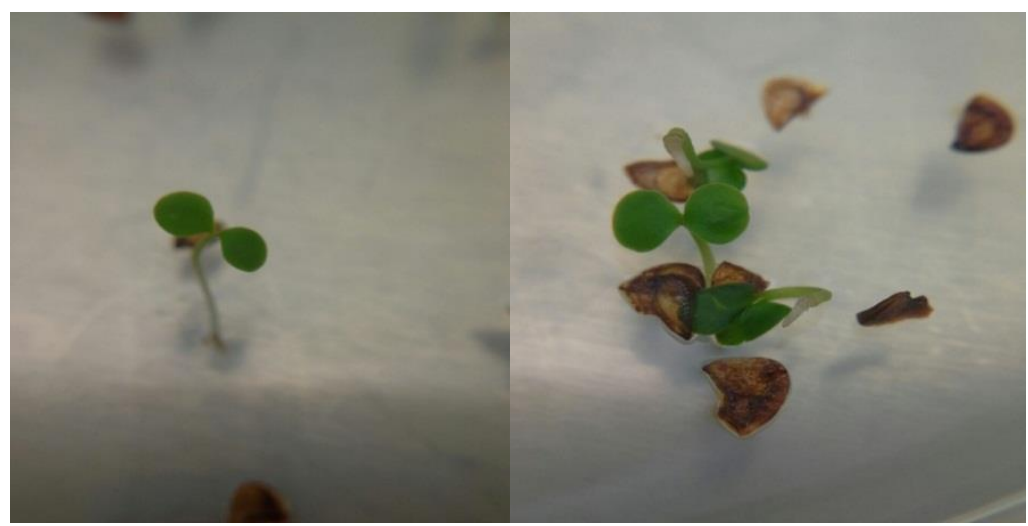

Gambar 2. Biji sowang yang telah berkecambah pada media VW yang dimodifikasi (kiri) dan media MS dengan zpt (kanan).

Tabel 1. Hasil analisis independent sample $t$ test terhadap hari muncul tunas (hst), persen perkecambahan (\%), rata-rata skor penampilan tunas (skor) dan rata-rata panjang tunas $(\mathrm{cm})$ biji sowang yang diinokulasi di media VW yang dimodifikasi dan MS dengan zpt.

\begin{tabular}{|c|c|c|c|c|}
\hline Parameter & Perlakuan & Mean \pm sd & $\mathrm{t}$ & sign. \\
\hline \multirow{2}{*}{ Hari muncul tunas (hst) } & VW yang dimodifikasi & $5.50 \pm 0.69$ & .244 & .809 \\
\hline & MS dengan zpt & $5.55 \pm 0.61$ & & \\
\hline \multirow{2}{*}{ Persen perkecambahan $(\%)$} & VW yang dimodifikasi & $63.55 \pm 14.45$ & .491 & .626 \\
\hline & MS dengan zpt & $61.40 \pm 13.19$ & & \\
\hline \multirow{2}{*}{ Penampilan tunas (skor) } & VW yang dimodifikasi & $2.85 \pm 0.37$ & .777 & .442 \\
\hline & MS dengan zpt & $2.75 \pm 0.44$ & & \\
\hline \multirow{2}{*}{ Panjang tunas $(\mathrm{cm})$} & VW yang dimodifikasi & $2.84 \pm 0.43$ & 1.251 & .218 \\
\hline & MS dengan zpt & $2.67 \pm 0.40$ & & \\
\hline
\end{tabular}

Hasil analisis di atas menunjukkan bahwa tidak ada perbedaan yang signifikan pada parameter hari muncul tunas, persen perkecambahan, penampilan tunas dan panjang 


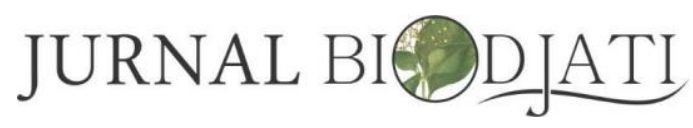

http://journal.uinsgd.ac.id/index.php/biodjati

tunas karena perlakuan jenis media inokulasi. Percobaan ini dihentikan pada 60 hst, karena secara visual panjang tunas sudah tidak bertambah. Pada fase pemeliharaan eksplan, seharusnya terdapat subkultur dengan media baru untuk mengganti media lama yang diduga telah habis kandungan unsur haranya. Subkultur tidak dapat dilakukan karena tunas yang tumbuh sangat rapuh, memiliki resiko mudah patah dan mati bila dipindahkan.

\section{PEMBAHASAN}

Pemilihan media dasar VW dan MS kultur in-vitro didasari oleh hasil-hasil penelitian sebelumnya terhadap biji yang tidak memiliki endosperm. Nurfadilah (2016) melaporkan bahwa media VW dan MS menghasilkan persen perkecambahan biji anggrek Dendrobium taurulinum yang relatif sama $(87.8 \%$ dan $87.7 \%)$ tetapi lebih baik secara signifikan dibandingkan dengan media Knudson C (81.2\%). Penggunaan media dasar VW untuk kultur biji anggrek Bulbophyllum echinolabium yang dilakukan oleh Warseno et al. (2013) mampu menghasilkan 86\% perkecambahan. Percobaan Djajanegara (2010) yang memanfaatkan $150 \mathrm{~mL}$ air kelapa pada kultur in-vitro biji anggrek bulan (Phakaenopsis amabilis) menghasilkan ratarata tertinggi, tinggi tunas $3.10 \mathrm{~cm}$ dan ratarata jumlah akar terbanyak 5.26. Sari tomat pada hasil penelitian Muharyati et al. (2015), terbukti berpengaruh terhadap pertumbuhan biji anggrek Vanda helvola, $24.1 \%$ protokorm terbentuk pada kultur 12 minggu. Deb \& Pongener (2011), menggunakan kombinasi 3 $\mu \mathrm{M}$ NAA dan $6 \mu \mathrm{M}$ BA dalam media dasar MS berhasil mencapai perkecambahan anggrek Cymbidium aloifolium $90 \%$ dalam jangka waktu 45 hari.

Rata-rata hari muncul tunas sowang 5.50 dan 5.55 hst tidak berbeda signifikan antara media VW dan media MS. Hari muncul tunas ini lebih singkat dari perkecambahan biji sowang pada media tanah dan pupuk kandang yang dilakukan oleh Wilujeng \& Agustini (2017) yakni 10 hst. Warseno, et al. (2013) melakukan penanaman biji anggrek Bulbophyllum echinolabium secara in-vitro, perkecambahan terjadi setelah satu tahun. Waktu mulai berkecambah sowang pada 5.50 - 5.55 hst di media in-vitro, sangat pendek bila dibandingkan dengan perkecambahan biji anggrek Bulbophyllum echinolabium.

Rata-rata persen perkecambahan biji sowang $63.55 \%$ dan $61.40 \%$ tidak berbeda signifikan antara perlakuan media yang diuji. Persen perkecambahan ini lebih tinggi dari persen perkecambahan $18 \%$ dari pengujian perkecambahan biji sowang Wilujeng \& Agustini (2017) pada media tanah dan pupuk kandang. Trivedi \& Joshi (2014) melaporkan bahwa biji Stereospermum suaveolens yang direndamselama 24 jam dalam aquadest, dikecambahkan pada media cocopeat, MS, tanah dan Woody Plant Medium (WPM) menghasilkan perkecambahan masing-masing $68 \%, 66 \%, 6 \%$ dan $0 \%$. Hasil penelitian ini menunjukkan bahwa MS menjadi media yang lebih baik untuk persen perkecambahan dibandingkan dengan media tanah. Media invitro tidak selalu dapat menjadi media perkecambahan setiap biji suatu spesies.

Rata-rata skor penampilan tunas yang diperoleh pada perlakuan media VW dan MS masing-masing 2.85 dan 2.75. Penilaian diberikan pada tunas yang berumur 60 hari setelah biji pertama berkecambah. Kedua ratarata skor tersebut tidak berbeda secara signifikan. Hasil penelitian Gultom et al. (2012) pada perkecambahan biji gaharu (Aquilaria malaccensis), menunjukkan kisaran skor penampilan tunas $0.86-1.85$ pada umur tunas 7 minggu. Bila dibandingkan dengan skor penampilan tunas gaharu pada umur tunas 


\section{JURNAL BIDDJATI}

http://journal.uinsgd.ac.id/index.php/biodjati

7 minggu, skor penampilan tunas sowang 60 hari relatif baik.

Panjang tunas diukur pada hari ke 60 setelah biji pertama berkecambah, diperoleh $2.84 \mathrm{~cm}$ pada media $\mathrm{VW}$ dan $2.67 \mathrm{~cm}$ pada media MS. Hasil $t$ test pada panjang tunas antara kedua media menunjukkan perbedaan yang tidak signifikan. Panjang tunas gaharu (Aquilaria malaccensis) pada penelitian Gultom et al. (2012), mencapai $0.76-1.84 \mathrm{~cm}$ pada minggu ke 7 setelah berkecambah. Panjang tunas sowang dapat dikategorikan relatif baik, bila dibandingkan dengan tunas gaharu.

Penelitian ini belum mencapai hasil seperti yang diharapkan yakni planlet sowang yang siap dipindahkan ke lokasi aklimatisasi. Pada hari ke 60 setelah biji pertama berkecambah, percobaan dihentikan. Secara visual, tunas sowang tidak menampakkan adanya pertumbuhan yang nyata, sementara subkultur tidak dapat dilakukan karena tunas sangat rapuh, memiliki resiko patah dan mati. Untuk itu, perlu dilakukan penelitianpenelitian lanjutan untuk mendapatkan media dan zat pengatur tumbuh yang sesuai bagi perkecambahan, pertumbuhan dan perkembangan tunas sowing. Pada media VW, diperlukan variasi modifikasi dari bahan organik yang digunakan atau variasi konsentrasi kombinasi bahan organik yang digunakan. Penggunaan media WPM juga perlu dicobakan mengingat sowang merupakan tumbuhan berkayu.

\section{UCAPAN TERIMA KASIH}

Ucapan terima kasih kepada DP2M Dikti Kementerian Riset Teknologi dan Pendidikan Tinggi atas dukungan dana melalui Penelitian Hibah Bersaing Perguruan Tinggi.

\section{DAFTAR PUSTAKA}

Deb, C. R., \& Pongener, A. J. (2011). Asymbiotic seed germination and in vitro seedling development of Cymbidium aloifolium (L) Sw : a multipurpose orchid. J. Plant Biochem. Biotechnol, 20 (1), 90 95.

Djajanegara, I. (2010). Pemanfaatan limbah buah pisang dan air kelapa sebagai bahan media kultur jaringan anggrek bulan (Phalaenopsis amabilis) tipe 229. J. TekLing, 11 (3), 373 -380.

Gultom, M.S., Anna, N., \& Siregar, E. B. M. (2012). Respon eksplan biji gaharu (Aquilaria malaccensis Lamk.) terhadap pemberian IAA secara in vitro. Peronema Forestry Science Journal, 1 (1), 1 - 6.

Muharyati, Y., Deviani, M. R., \& Astiti, N. P. A. (2015). Pertumbuhan anggrek Vanda helvola pada media yang diperkaya jus tomat. Jurnal Metamorfosa, 11 (2), 66 71.

Nurfadilah, S. (2016). The effect of culture media and activated charcoal on asymbiotic seed germination and seedling development of a threatened orchid Dendrobium taurulinum J. J. Smith in vitro. Berita Biologi, 15 (1), 49 - 57.

Trivedi, D. R., \& Joshi, A. G. (2014). Studies on seed germination of Stereospermum suaveolens with respect to different parameters. Environmental and Experimental Biology, 12, 33-37.

Warseno, T., Hendriyani, E., \& Priyadi, A. (2013). Konservasi dan propagasi Bulbophyllum echinolabium J. J. SM melalui kultur in vitro. Prosiding Ekspose dan Seminar Pembangunan Kebun Raya Daerah : Membangun Kebun Raya Untuk Penyelamatan Keanekaragaman Hayati dan Lingkungan Menuju Ekonomi Hijau. 


\section{JURNAL BIDJATI}

http://journal.uinsgd.ac.id/index.php/biodjati

Bogor, 25 - 26 November 2013. Hlm 773 783.

Whitmore, T. C., Tantra, I. G. M \& Sutisna, U. (1997). Tree flora of Indonesia check list for Irian Jaya. Agency for Forestry Research and Development. Bogor : Forest Research and Development Centre.

Wilson, P. G. \& Pitisopa, F. (2007). Xanthostemon melanoxylon (Myrtaceae)a new species from the Solomon Islands. Telopea, 11 (4), $399-403$.

Wilujeng, S. (2010). The effects of forest burning and logging toward regeneration ability of sowang (Xanthostemon novaguineense Valet.) in Cycloop Mountain, Jayapura, Papua. Biodiversitas, 11 (4), $194-199$.

Wilujeng, S \& Simbiak, M. (2015). Karakteristik morfologi Xanthostemon novoguineensis Valeton (Myrtaceae) dari Papua. Pros Sem Nas Masy Biodiv Indon, 1 (3), 466-471.

Wilujeng, S., \& Agustini, V. (2017). Studi awal regenerasi sowang (Xanthostemon novaguineense Valet.). Jurnal Biologi Papua, 9 (1), 31 - 36.

Yusnita, \& Handayani, Y. (2011). Pengecambahan biji dan pertumbuhan seedling Phalaenopsis hibrida in-vitro pada dua media dasar dengan atau tanpa arang aktif. Jurnal Agrotropika, 16 (2),7075. 